Article

\title{
Two Complementary Synthetic Approaches to the Enantiomeric Forms of the Chiral Building Block (2,6,6-Trimethyltetrahydro-2H-pyran-2-yl)methanol: Application to the Stereospecific Preparation of the Natural Flavor Linaloyl Oxide
}

\author{
Stefano Serra * (iD and Davide De Simeis \\ Consiglio Nazionale delle Ricerche (C.N.R.) Istituto di Chimica del Riconoscimento Molecolare, Via Mancinelli 7, \\ 20131 Milano, Italy; dav.biotec01@gmail.com \\ * Correspondence: stefano.serra@cnr.it or stefano.serra@polimi.it; Tel.: +39-02-2399 3076
}

Received: 12 August 2018; Accepted: 26 August 2018; Published: 28 August 2018

check for updates

\begin{abstract}
The enantiomeric forms of the alcohol (2,6,6-trimethyltetrahydro-2H-pyran-2-yl)methanol are potential chiral building blocks for the stereoselective synthesis of different natural terpenes. Here, we describe their preparation by means of two different synthetic approaches. The first is based on the stereospecific (+)-10-camphorsulfonic acid (CSA)-catalyzed cyclization of $(R)$ - and (S)-2-methyl-5-(2-methyloxiran-2-yl)pentan-2-ol, which were in turn synthesized from $(R)$ - and (S)-linalool, respectively. The latter monoterpenes are easily available from the chiral pool, with different optical purity. As our synthesis makes use of the intermediate 2,6-dimethyloct-7-ene-2,6-diol, whose enantiopurity can be improved through fractional crystallization, we obtained (2,6,6-trimethyltetrahydro-2H-pyran-2-yl)methanol enantiomers in an almost enantiopure form. The second synthetic approach is based on the lipase-mediated resolution of the aforementioned tetrahydropyranyl alcohol, which was prepared in racemic form starting from the industrial intermediate, dehydrolinalool. In this work, we report a large-scale resolution procedure that exploits the opposite enantioselectivity of Novozym ${ }^{\circledR} 435$ lipase and lipase $\mathrm{AK}$ in the acetylation reaction of (2,6,6-trimethyltetrahydro-2H-pyran-2-yl)methanol. The two enantiomeric forms of the latter alcohol were employed for the first stereoselective synthesis of both enantiomers of the flavor, linaloyl oxide (2,2,6-trimethyl-6-vinyltetrahydro-2H-pyran).
\end{abstract}

Keywords: linalool; cyclization; enantioselective synthesis; enzyme-mediated resolution; lipases; flavors; monoterpenes; linaloyl oxide

\section{Introduction}

Tetrahydropyrane and tetrahydrofurane derivatives having the general framework of type $\mathbf{2}$ and 3 (Figure 1) are quite common naturally occurring compounds. The biosynthesis of the main part of these ethers is based on the cyclization of a terpenic alcohols of type $\mathbf{1}$, and follows two main pathways, both involving the intramolecular nucleophilic addition of a hydroxyl functional group to a terminal prenyl group [1,2].

A first path requires the preliminary activation of the double bond through its transformation in epoxide or halonium derivatives, which easily cyclizes to give the corresponding ether derivatives bearing an additional hydroxyl or halogen functional group. Due to the general interest in this kind of chemical transformation in organic synthesis, its regio- and stereochemical outcomes were studied in depth [3-5]. In addition, the monoterpenes possessing a hydroxyl group and a vinyl group $(\mathrm{E}=\mathrm{OH}$, 
$\mathrm{R}=$ vinyl) are well-known flavor components collectively called linalool oxides, regardless of the fact that they possess a six- or five-membered ring [6].

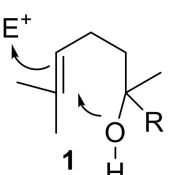

$1 \stackrel{\text { ! }}{\mathrm{H}}$

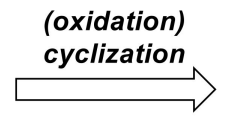
Figure 1. The transformation of te
derivatives 2 and 3 , respectively.

Figure 1. The transformation of terpenic alcohols of type $\mathbf{1}$ into tetrahydropyrane and tetrahydrofurane

On the contrary, the cyclization path which does not involve a preliminary oxidation reaction affords tetrahydropyrane and tetrahydrofurane derivatives devoid of a hydroxyl group $(E=H)$. Although a number of pyranoid derivatives possessing these structural frameworks were identified in nature, only few stereoselective approaches to their synthesis are described so far. For example linaloyl oxide (Compound 4) enantiomers (Figure 2) are relevant flavor and fragrance components [7-20], sydowic acid (Compound 5) is a bioactive sesquiterpene produced by the mold Aspergillus sidowii [21], the diterpenic diol (Compound 6) was isolated from the African plant Anisopappus pinnatifidus [22], and triterpene panaxadiol (Compound 7) is a bioactive component of the ginseng extract [23]. These terpenes share in common the same tetrahydropyranyl moiety which contains a quaternary stereocenter, whose stereoselective construction is especially demanding.

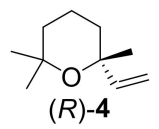

2,2,6-trimethyl-6-

vinyltetrahydro-2H-pyran

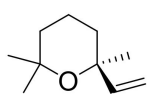

(S) -4

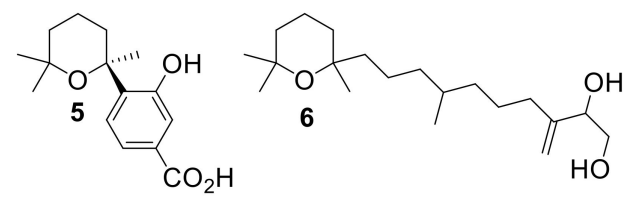

(S)-sydowic acid

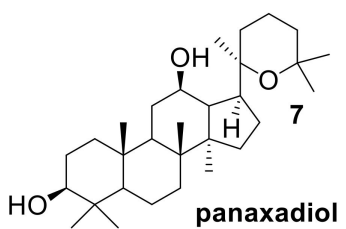

Figure 2. Representative examples of natural terpenes (mono-, sesqui-, di-, and triterpenes) bearing the 2,6,6-trimethyltetrahydro-2H-pyran-2-yl moiety in their molecular framework.

As we are involved in a number of studies describing the stereoselective synthesis of flavors and fragrances [24-28], and as we recently reported a new enantioselective synthesis of pyranoid linalool oxide isomers [29], we became interested in expanding our studies to the above-described class of compounds. More specifically, we envisaged that the enantiomeric forms of the primary alcohol (2,6,6-trimethyltetrahydro-2H-pyran-2-yl)methanol (Compound 8; Figure 3) could be regarded as potential building blocks for the stereoselective synthesis of this kind of natural product.

According to our retrosynthetic analysis, we devised two different synthetic methods for the stereoselective preparation of alcohol 8. Both approaches are based on an enantioselective-catalyzed reaction as key step. The first procedure takes advantage of the stereospecific (+)-10-camphorsulfonic acid (10-CSA)-catalyzed cyclization of $(R)$ - and (S)-enantiomers of 2-methyl-5-(2-methyloxiran-2-yl)pentan-2-ol (Compound 9), which were in turn synthesized from $(R)$ - and $(S)$-enantioforms of linalool (Compound 10), respectively. The latter cyclization reaction proceeds with very high stereocontrol as previously described by Vidari [30,31], who studied this chemical transformation using very similar epoxides as substrates. In addition, both linalool enantiomers are accessible from the chiral pool with different optical purity [32].

The second approach is based on the lipase-mediated resolution of the racemic alcohol 8, in turn obtained by reduction of the easily available cinenic acid (Compound 11) [33]. 


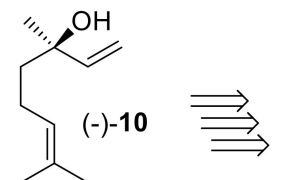

$(R)$-linalool

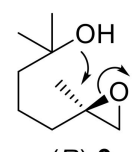

$(R)-9$

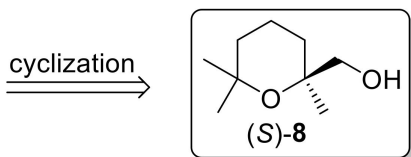

$(S)-8$

S)-linalool

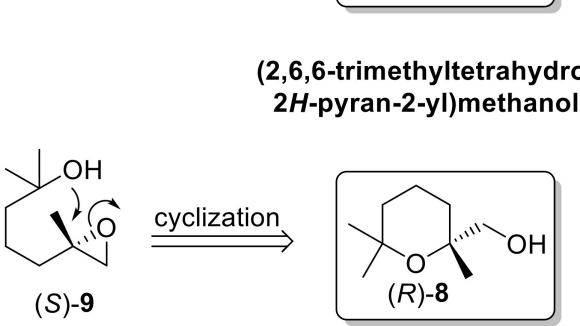

(S)-9
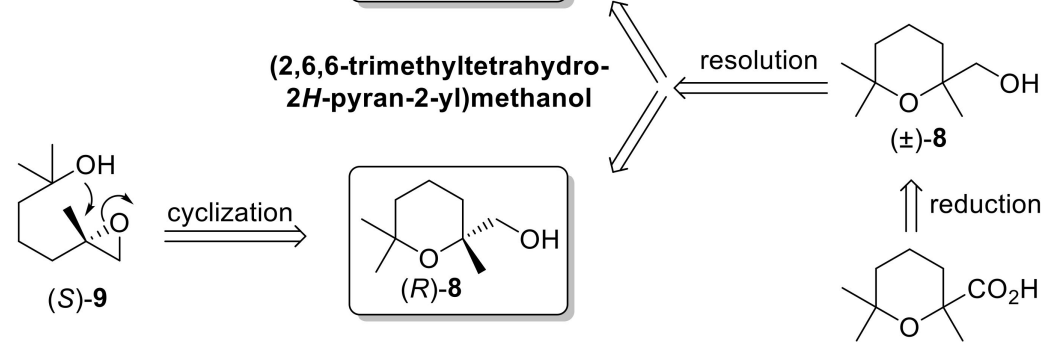

$( \pm)-11$

cinenic acid

Figure 3. The retrosynthetic analysis of the enantiomeric forms of (2,6,6-trimethyltetrahydro-2H-pyran-2-yl)methanol 8. Two different approaches are proposed: the first is based on stereoselective synthesis (left) and the second is based on the resolution of racemic 8 (right).

Although we already reported the resolution of racemic $\mathbf{1 1}$ by means of the fractional crystallization of its $(R)-1$-phenylethylamine salt [34], the application of this procedure for the preparation of both enantiomers of the aforementioned acid turned out to be lengthy because of the necessary sequential preparation of both $(R)$ - and $(S)$-phenylethylamine salts. In order to avoid the tedious chemical manipulations related to the salt formation, as well as to the number of crystallizations required, we investigated the lipase-mediated acetylation reaction of alcohol 8 using vinyl acetate as an acetyl donor. According to this approach, the enzymes are able to catalyze the esterification reaction with high enantioselectivity, allowing the separation of (2,6,6-trimethyltetrahydro-2H-pyran-2-yl)methanol isomers. One enantiomer gives the corresponding acetate, and the other does not react. A simple chromatographic separation is required to complete the resolution procedure.

In the present work, we describe the accomplishment of the two above-described synthetic approaches. More specifically, we report in detail the synthetic procedure that allows transforming enantioenriched linalool into enantiopure (2,6,6-trimethyltetrahydro-2H-pyran-2-yl)methanol enantiomers. Moreover, we describe a large-scale resolution procedure that exploits the opposite enantioselectivity of two different lipases in the acetylation reaction of alcohol 8. Thanks to the sequential use of both enzymes, the two enantiomeric forms of the alcohol were obtained in very high enantiomeric purity and were employed for the first stereoselective synthesis of both enantiomers of the natural flavor, linaloyl oxide (2,2,6-trimethyl-6-vinyltetrahydro-2H-pyran).

\section{Results and Discussion}

As mentioned in the introduction, we selected epoxide 9 as a synthetic precursor of alcohol 8. We planned the enantioselective synthesis of both epoxide enantiomers using linalool enantiomers as starting materials. From a synthetic standpoint, the different reactivity of the two double bonds present in the linalool framework allows an outline of the regioselective preparation of $\mathbf{9}$. Indeed, the tertiary hydroxy group can be introduced via regioselective epoxidation/reduction of the trisubstituted linalool double bond (Figure 4). Furthermore, the epoxide functional group can be introduced by oxidative cleavage of the monosubstituted linalool double bond followed by reduction to the corresponding 1,2-diol. The latter intermediate can be transformed into epoxide 9 by activation of the primary hydroxy group followed by a ring-closure reaction. 

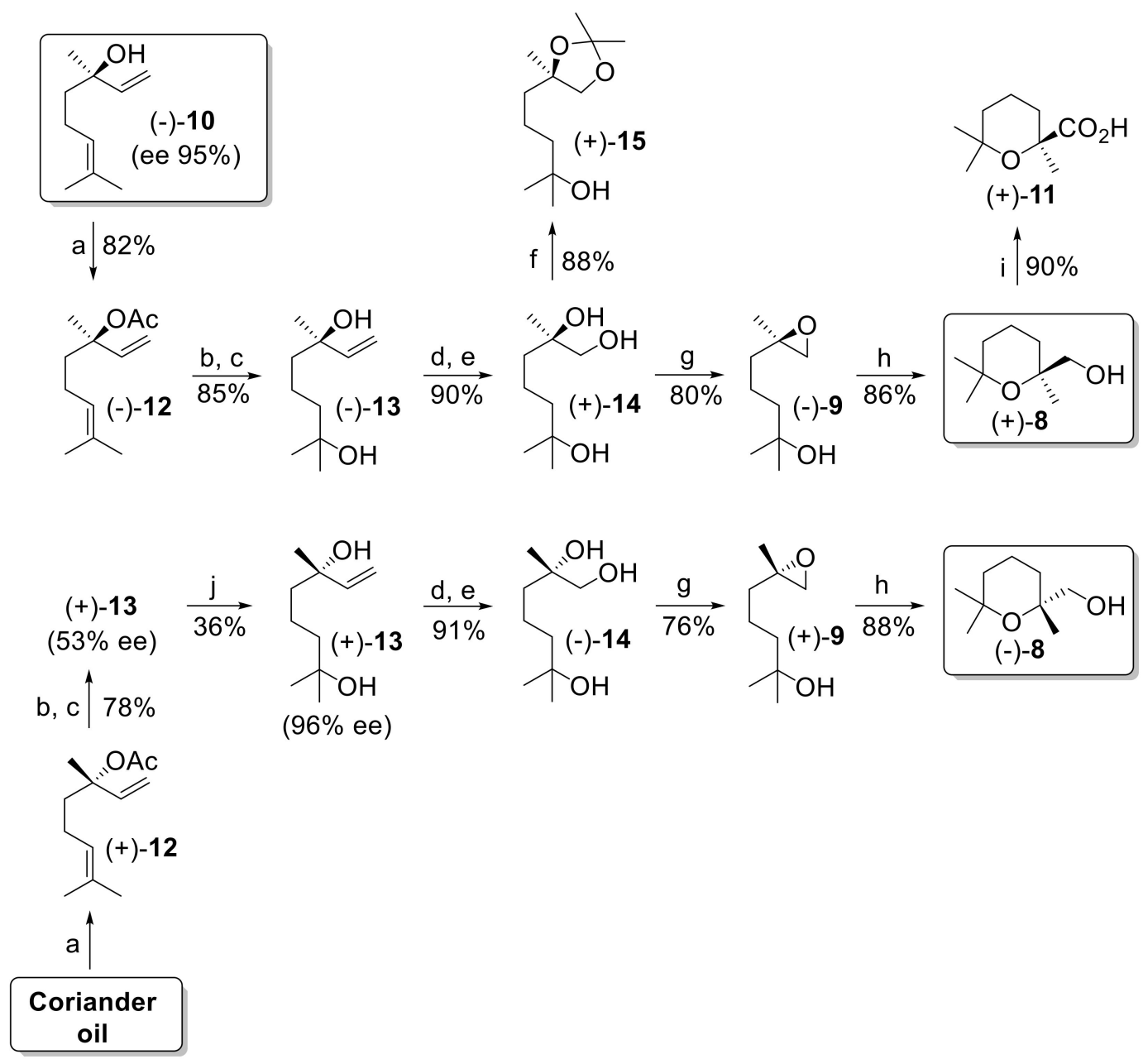

Figure 4. Stereoselective synthesis of $(S)$ - and (R)-2,6,6-trimethyltetrahydro-2H-pyran-2-yl)methanol 8 starting from $(R)$ - and $(S)$-linalool 10, respectively. Reagents and conditions: (a) $\mathrm{Ac}_{2} \mathrm{O} /$ pyridine (Py), 4-dimethylaminopyridine (DMAP) catalyst, reflux $2 \mathrm{~h}$; (b) $m$-chloroperbenzoic acid $(m \mathrm{CPBA}), \mathrm{CH}_{2} \mathrm{Cl}_{2}$, $0{ }^{\circ} \mathrm{C}$; (c) $\mathrm{LiAlH}_{4}$, dry tetrahydrofuran (THF), reflux $5 \mathrm{~h}$; (d) $\mathrm{O}_{3}, \mathrm{DMAP},-15^{\circ} \mathrm{C}$, then $\mathrm{TsCl} 0{ }^{\circ} \mathrm{C}, 3 \mathrm{~h}$; (h) (+)-10-camphorsulfonic acid (CSA) catalyst, $\mathrm{CH}_{2} \mathrm{Cl}_{2}, 0{ }^{\circ} \mathrm{C}, 2 \mathrm{~h}$; (i) $\mathrm{CrO}_{3} /$ aqueous $\mathrm{H}_{2} \mathrm{SO}_{4}$, acetone, $0{ }^{\circ} \mathrm{C}$ to room temperature $(\mathrm{rt}), 1 \mathrm{~h} ;(\mathrm{j})$ three crystallizations from hexane.

At first, we accomplished this synthetic approach starting from a sample of $(-)-(R)$-linalool that is commercially available in very high enantiomeric purity by extraction from Cinnamomun canphora (95\% enantiomeric excess (ee)). Accordingly, the tertiary alcohol (-)-10 was refluxed with acetic anhydride and pyridine (Py) in presence of catalytic amount of 4-dimethylaminopyridine (DMAP), to give the corresponding acetate (-)-12. The latter ester was treated with $m$-chloroperbenzoic acid $(m \mathrm{CPBA})$ in $\mathrm{CH}_{2} \mathrm{Cl}_{2}$ and the resulting crude epoxide was regioselectively reduced using an excess of $\mathrm{LiAlH}_{4}$ in refluxing tetrahydrofuran (THF). The obtained diol (-)-13 was first purified by crystallization from hexane and then treated with ozone in $\mathrm{CH}_{2} \mathrm{Cl}_{2} / \mathrm{MeOH}$, until complete cleavage of the double bond. The following reduction with $\mathrm{NaBH}_{4}$ afforded the triol (+)-14 in very good yield. Compound 14 could not be characterized by NMR analysis as the strong inter- and intramolecular hydrogen bonding broadened both ${ }^{1} \mathrm{H}$ - and ${ }^{13} \mathrm{C}-\mathrm{NMR}$ signals to such an extent that we could not properly describe the spectra. Since the latter compound is previously undescribed, we prepared the dioxolane (+)-15 by reaction of (+)-14 with 2,2-dimethoxypropane (2,2-DMP) in acetone in presence of a pyridinium $p$-toluenesulfonate (PPTS) catalyst. Thus, the derivative (+)-15 was fully characterized, and the analytical data confirmed both the regioisomeric purity and the chemical structure of triol 14 . The transformation of the 1,2-diol functional group into an epoxide group was performed as described 
by Vidari [30], using lithium diisopropylamide (LDA) and tosyl chloride in THF solution at $-10^{\circ} \mathrm{C}$. The obtained epoxy-alcohol (-)-9 was treated with a catalytic amount of (+)-10-CSA to give the desired (2,6,6-trimethyltetrahydro-2H-pyran-2-yl)methanol (+)-8 in good yield. The absolute configuration of $(+)-8$ was confirmed to be $(S)$ by chemical correlation with cinenic acid. Accordingly, oxidation of (+)-8 with Jones reagent afforded $(+)$-cinenic acid $\mathbf{1 1}$ of known $(S)$ configuration [35].

In order to also obtain the compound (-)-8, we accomplished the identical reaction sequence described above starting from (+)-linalool. The latter compound is easily available from coriander oil whose weight is made up of more than $90 \%(+)-10$. The direct treatment of the essential oil with acetic anhydride and pyridine in presence of a catalytic amount of DMAP, followed by purification by distillation, gave the corresponding acetate (+)-12 in good yield. Unfortunately, the enantiomeric purity of (+)-linalool from this botanic source ranges from 45 to $85 \%$ ee [32], which is not suitable for the preparation of the chiral building block 8 . Since our synthesis makes use of the intermediate 2,6-dimethyloct-7-ene-2,6-diol 13, which can be purified by crystallization, we observed that, starting from $(-)-(R)$-linalool showing $95 \%$ ee, the optical rotation value of the resulting diol was $-9.9^{\circ}$ which increased to $-10.4^{\circ}$ after crystallization. Similarly, diol (+)-13 derived from a commercial sample of coriander oil (optical purity of the linalool of about $55 \%$ ee) showed an optical rotation value of $+5.2^{\circ}$, which increased to $+10.1^{\circ}$ after three crystallizations from hexane. These results demonstrate that the enantiopurity of diol 13 was improved through fractional crystallization passing from $53 \%$ ee to $96 \%$ ee. Therefore, the described purification procedure allows the proper enantioselective synthesis of both enantioforms of compound 8 .

Accordingly, the achieved enantiopure diol (+)-13, was transformed into alcohol (-)-8, following the experimental conditions used for the synthesis of alcohol (+)-8. Overall, both enantioforms of the building block (2,6,6-trimethyltetrahydro-2H-pyran-2-yl)methanol were achieved in optical purity superior to $95 \%$ ee.

The second part of this work, namely the development of an enzyme-mediated resolution procedure of alcohol $( \pm)-8$, first requires a valuable amount of the aforementioned racemic alcohol. Hence, we devised the preparative procedure described in Figure 5, which improved the cinenic acid synthesis previously reported by Rupe and Lang [33].

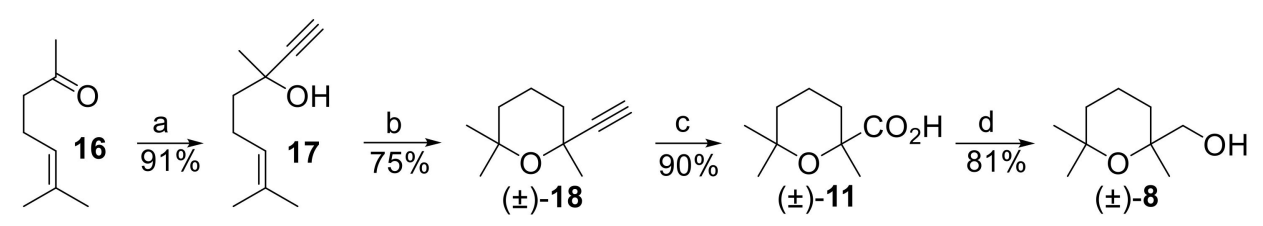

Figure 5. Synthesis of racemic 2,6,6-trimethyltetrahydro-2H-pyran-2-yl)methanol 8 starting from 6-methylhept-5-en-2-one 16. Reagents and conditions: (a) ethynylmagnesium bromide, THF dry, $-70{ }^{\circ} \mathrm{C}$ to rt, $2 \mathrm{~h}$; (b) $\mathrm{HCOOH} / \mathrm{H}_{2} \mathrm{O}$ 85:15, reflux $30 \mathrm{~min}$; (c) $\mathrm{NaIO}_{4}, \mathrm{RuCl}_{3} \cdot \mathrm{H}_{2} \mathrm{O}$ catalyst, $\mathrm{CCl}_{4} / \mathrm{CH}_{3} \mathrm{CN} / \mathrm{H}_{2} \mathrm{O}$ 2:2:3, rt, $24 \mathrm{~h}$; (d) $\mathrm{ClCOOEt} / \mathrm{Et}_{3} \mathrm{~N}$, dry THF, $-10{ }^{\circ} \mathrm{C}$, one hour, then $\mathrm{NaBH}_{4}$, $\mathrm{H}_{2} \mathrm{O}, 0{ }^{\circ} \mathrm{C}$ to rt, $4 \mathrm{~h}$.

Accordingly, the addition of ethynylmagnesium bromide to 6-methylhept-5-en-2-one (Compound 16) afforded dehydrolinalool (Compound 17), which was then heated at reflux in formic acid/water to give 2-ethynyl-2,6,6-trimethyltetrahydro-2H-pyran (Compound 18).

The oxidation of the alkyne 18 to cinenic acid 11, performed using Rupe and Lang procedure, makes use of aqueous $\mathrm{KMnO}_{4}$, and the yield of the isolated acid does not exceed $50 \%$, even with complete conversion of the alkyne. Therefore, we employed a different oxidation method based on the use of $\mathrm{NaIO}_{4}$, in the presence of a catalytic amount of $\mathrm{RuCl}_{3} \cdot \mathrm{H}_{2} \mathrm{O}$ [36]. As a result, cinenic acid was obtained in very good yield $(90 \%)$. Finally, the transformation of the carboxylic acid functional group of $\mathbf{1 1}$ into the corresponding carboxy-ethyl derivative followed by reduction with $\mathrm{NaBH}_{4}$ [37] smoothly afforded racemic 8 , in good overall yield. 
To the best of our knowledge, no enzyme-mediated resolution procedures of (2,6,6-trimethyltetrahydro-2H-pyran-2-yl)methanol are reported until now. It should be noted that, usually, lipases catalyze the esterification of primary alcohols with very low enantioselectivities. Since we already described some remarkable exceptions to this behavior [38-41], we decided to investigate the reactivity of racemic 8 in the latter reaction, using a number of selected lipases. For each experiment, 8 was treated with vinyl acetate in $t$-butyl-methyl ether, in the presence of the given enzyme (Figure 6). The reactions were interrupted when the wanted conversion was achieved. The unreacted alcohol and the acetate 19 were separated by chromatography, and their enantiomeric compositions were determined by comparing their optical rotation values with those measured for the same enantiopure chemical compounds. The results are summarized in Table 1.

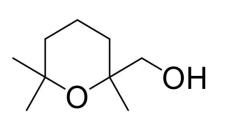

$( \pm)-8$

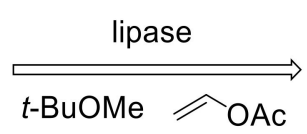

OAC

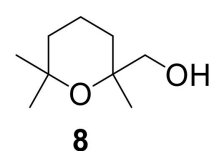

8

(unreacted)

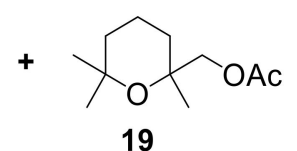

19

Figure 6. Lipase-mediated acetylation of racemic (2,6,6-trimethyltetrahydro-2H-pyran-2-yl)methanol 8. Reagents and conditions: $t$-BuOMe/vinyl acetate 5:1, rt, concentration of $( \pm)-8: 1 \mathrm{M}$. Results are collected in Table 1.

Table 1. Results of the enzyme-mediated acetylation of racemic alcohol 8.

\begin{tabular}{cccccc}
\hline $\begin{array}{c}\text { Racemic } \\
\text { Alcohol }\end{array}$ & Enzyme & $\begin{array}{c}\text { Acetate/Configuration } \\
\text { (Enantiomeric Excess (ee)) }\end{array}$ & $\begin{array}{c}\text { Time } \\
\text { (Days) }\end{array}$ & $\begin{array}{c}\text { Conversion } \\
\text { (\%) }\end{array}$ & $\begin{array}{c}\text { Enantiomer } \\
\text { Ratio (E) }^{2}\end{array}$ \\
\hline & PS (Amano) & $(-)-19 / 2 R(61 \%$ ee) & 3 & 44 & 6.5 \\
& PPL & - & 14 & $<10$ & - \\
$( \pm)-8$ & CRL & $(+)-19 / 2 S(4 \%$ ee) & $0.5 \mathrm{~h}$ & 29 & 1.1 \\
& Novozym 435 & $(+)-19 / 2 S(81 \%$ ee) & 3 & 40 & 16.3 \\
& PLE on Eupergit & 1 & - & - & - \\
& Lipase AK (Amano) & $(-)-19 / 2 R(79 \%$ ee) & 4 & 40 & 13.7 \\
\hline
\end{tabular}

1 After 10 days, the thin-layer chromatography (TLC) analysis of the reaction mixture did not detect the presence of the acetate; ${ }^{2} \mathrm{E}=\ln \left(1-\mathrm{c} \times\left(1+\mathrm{ee}_{\mathrm{p}}\right)\right) / \ln \left(1-\mathrm{c} \times\left(1-\mathrm{ee}_{\mathrm{p}}\right)\right)$, [42]. PPL-porcine pancreatic lipase; CRL-lipase from Candida rugosa; PLE-pig liver esterase.

The perusal of the obtained data allows drawing some relevant considerations. Firstly, we can observe that porcine pancreatic lipase (PPL) and pig liver esterase (PLE on Eupergit) were completely inactive. The reaction with PPL afforded only a trace of the acetate 19 after a long reaction time. This behavior is in sharp contrast with the results obtained in our previous studies where the same enzymes showed a remarkable catalytic activity in the acetylation of different primary alcohols. On the contrary, all the other enzymes evaluated in this work showed high activity, although with different stereoselectivity. More specifically, lipase PS and lipase AK (both from Amano Pharmaceuticals) catalyze the acetylation of $(R)-8$ in modest $(\mathrm{E}=6.5)$ and good $(\mathrm{E}=13.7)$ enantioselectivities, respectively. Moreover, lipase from Candida rugosa (CRL) and Novozym 435 lipase catalyze the acetylation of $(S)-8$ in very low $(E=1.1)$ and good $(E=16.3)$ enantioselectivities, respectively. It is worth noting that CRL is a very effective catalyst, but does not show any enantioselectivity, thus making the enzyme unsuitable for any resolution process. Overall, we identified two enzymes, namely Novozym 435 and lipase AK, that are able to catalyze the acetylation of racemic alcohol 8 with good enantioselectivity. Both enzymes are suitable for setting up a resolution process, but they display opposite enantiopreference. Taking advantage of this observation, we devised a large-scale resolution procedure (Figure 7) based on the combined and sequential use of Novozym 435 lipase and lipase AK. 


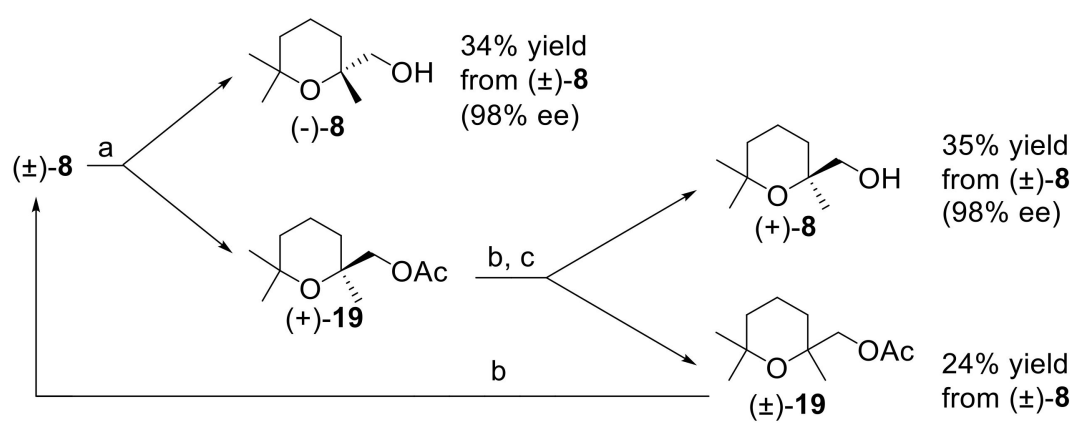

Figure 7. Large-scale resolution procedure of racemic 2,6,6-trimethyltetrahydro-2H-pyran-2-yl)methanol 8. Reagents and conditions: (a) Novozym ${ }^{\circledR} 435$ lipase, $t$-BuOMe/vinyl acetate $5: 1, \mathrm{rt}$; (b) $\mathrm{NaOH} / \mathrm{MeOH}$, reflux, $1 \mathrm{~h}$; (c) lipase AK, $t$-BuOMe/vinyl acetate 5:1, rt.

Hence, racemic 8 was treated with vinyl acetate in $t$-BuOMe using Novozym 435 as catalyst. The acetylation reaction was prolonged until about $65 \%$ conversion was reached. In accord with the specific lipase enantioselectivity and with the general rules of the enzyme-based kinetic resolution of racemic mixtures [42], the unreacted alcohol $(-)-(R)-8$ was isolated in about $34 \%$ yield and in very high enantiopurity (98\% ee). On the contrary, the acetate (+)-19 possessed low optical purity and was hydrolyzed using $\mathrm{NaOH}$ in methanol. The resulting alcohol (+)-8 was submitted to a second acetylation step, using lipase AK as catalyst. Indeed, the latter enzyme catalyzes the esterification of the (-)-(R) enantiomer of alcohol 8 , which was transformed in the corresponding acetate. As (-)-8 is the minor component of the enantiomers mixture, the enzymatic reaction increased the enantiomeric purity of the unreacted alcohol. After the acetylation reaction reached a conversion of about $60 \%$, the alcohol (+)-8 was isolated in about $35 \%$ overall yield and with $98 \%$ ee. Nearly racemic acetate 19 was also obtained and it could be hydrolyzed to recover further alcohol, to be used in a new resolution procedure.

Overall, our resolution procedure proved to be compact, effective, and user-friendly as it can afford both enantiomeric forms of (2,6,6-trimethyltetrahydro-2H-pyran-2-yl)methanol in very high optical purity by means of two commercial enzymes and without the employment of demanding experimental conditions or reagents.

As a first synthetic application of the obtained chiral building blocks, we describe here the preparation of $(R)$ - and (S)-linaloyl oxide 4 starting from $(R)$ - and (S)-(2,6,6-trimethyltetrahydro-2H-pyran-2-yl)methanol 8 , respectively. As mentioned in the introduction, this monoterpene is a relevant fragrance/flavor ingredient [43]. More specifically, it is one of the fragrance components of geranium and lime essential oil $[7,8]$ and is a trace component of the flavor of many fruits or other vegetal species [9-20]. Since an effective and cheap synthesis of racemic 4 was established [44], linaloyl oxide is currently produced and commercialized in this form, under the trade name Limetol ${ }^{\circledR}$ (Givaudan).

We are not aware of any olfactory evaluation of the single enantiomeric forms of this monoterpene that seems to occur in essential oils in nearly racemic form [8]. Since the organoleptic evaluation of this compound is subject to the availability of both $(R)$ and $(S)$ isomers in high enantiomeric purity, their stereoselective synthesis is highly desired. To date, only a lengthy and low-yielding synthesis of (+)-4 was reported in the course of a study finalized to the characterization of linalool oxide [45]. As the starting compound was (-)-linalool, a similar approach for the preparation of enantiopure (-)-4 is not applicable, as (+)-linalool is available in low enantiomeric purity. Therefore, we synthesized $(R)$ - and $(S)$-linaloyl oxide starting from enantiopure $(R)$ - and (S)-(2,6,6-trimethyltetrahydro-2H-pyran-2-yl)methanol 8, respectively, as described in Figure 8. 


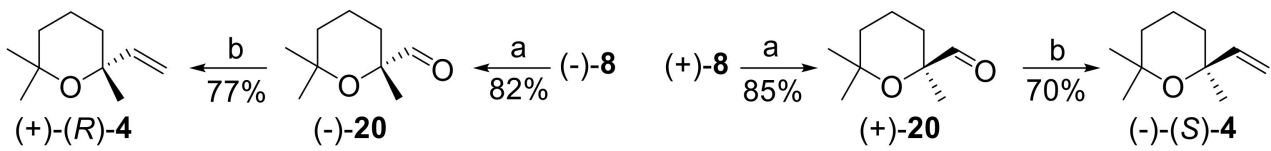

Figure 8. Synthesis of $(R)$ - and (S)-linaloyl oxide 4 starting from $(R)$ - and (S)-(2,6,6-trimethyltetrahydro-2H-pyran-2-yl)methanol 8, respectively. Reagents and conditions: (a) Py. $\mathrm{SO}_{3}$, dimethyl sulfoxide (DMSO), $\mathrm{Et}_{3} \mathrm{~N}$, rt, $2 \mathrm{~h}$; (b) $\mathrm{Zn}, \mathrm{CH}_{2} \mathrm{I}_{2}, \mathrm{Me}_{3} \mathrm{Al}$, dry $\mathrm{THF}, 0{ }^{\circ} \mathrm{C}$, one hour.

Accordingly, the alcohols $(-)$ and (+)-8 were oxidized in good yields to the corresponding aldehydes (-) and (+)-20, respectively, using $\mathrm{Py} \cdot \mathrm{SO}_{3}$ in dimethyl sulfoxide (DMSO)/ $\mathrm{Et}_{3} \mathrm{~N}$ [46]. Then, the $C_{9}$ aldehydes 20 were homologated to the $C_{10}$ ethers 4 through a methylenation reaction. The most used method to perform this transformation, namely the Wittig reaction using triphenylphosphoniummethylene ylide, was not successful, as only the degradation of the starting aldehyde was observed. On the contrary, we found that the reagent obtained by reaction of $\mathrm{Zn}$, $\mathrm{CH}_{2} \mathrm{I}_{2}$, and $\mathrm{Me}_{3} \mathrm{Al}$ [47] effectively converted (-) and (+)-20 into ether (+) and (-)-4, respectively. Overall, the described reaction sequence is high yielding and did not involve loss of optical purity. Since the starting chiral building blocks are enantiopure, the obtained linaloyl oxide enantiomers are suitable for olfactory evaluation, the study of which will be reported in due course.

\section{Materials and Methods}

\subsection{Materials and General Methods}

All moisture- and air-sensitive reactions were carried out using dry solvents under a static atmosphere of nitrogen.

All solvents and reagents were of commercial quality and were purchased from Sigma-Aldrich (St. Louis, MO, USA) with the exception of (S)-linalool acetate (+)-12 and dehydrolinalool 17 (3,7-dimethyloct-6-en-1-yn-3-ol), which were prepared by acetylation of coriander oil and by addition of ethynylmagnesium bromide to 6-methylhept-5-en-2-one 16, respectively.

$(-)-(R)$-Linalool, extracted from Cinnamomun canphora (L.) and possessing $99 \%$ purity by GC and $[\alpha]_{\mathrm{D}}^{20}=-20.9$ (neat), was purchased from Sigma-Aldrich (lot MKBR2739V).

Coriander oil, $[\alpha]_{\mathrm{D}}^{20}=+8.3$ (neat), was purchased from Sigma-Aldrich (lot MKCC6867) and was used as source of $(+)-(S)$-linalool.

Lipase from Porcine pancreas (PPL) type II, Sigma-Aldrich, 147 units/mg; lipase from Pseudomonas cepacia (PS), Amano Pharmaceuticals Co., Tokyo, Japan, 30 units/mg; lipase from Candida rugosa (CRL) type VII, Sigma-Aldrich, $\geq 700$ units/g; Novozym ${ }^{\circledR} 435$, Novozymes, $\geq 5000$ units/g; lipase AK Amano from Pseudomonas fluorescens, Sigma-Aldrich, 20 units/mg; and PLE on Eupergit, Sigma-Aldrich, 200 units/g were employed in this work.

\subsection{Analytical Methods and Characterization of the Chemical Compounds}

${ }^{1} \mathrm{H}$ and ${ }^{13} \mathrm{C}-\mathrm{NMR}$ spectra and DEPT (Distortionless enhancement by polarization transfer) experiments: $\mathrm{CDCl}_{3}$ solutions at room temperature (rt) using a Bruker-AC-400 spectrometer (Billerica, MA, USA) at 400, 100, and $100 \mathrm{MHz}$, respectively; ${ }^{13} \mathrm{C}$ spectra are proton-decoupled; chemical shifts in ppm relative to internal $\mathrm{SiMe}_{4}(0 \mathrm{ppm})$.

Thin-layer chromatography (TLC) involved the use of Merck silica gel $60 \mathrm{~F}_{254}$ plates (Merck Millipore, Milan, Italy), while column chromatography involved the use of silica gel.

Melting points were measured on a Reichert apparatus, equipped with a Reichert microscope, and are uncorrected.

Optical rotations were measured on a Jasco-DIP-181 digital polarimeter (Jasco, Tokyo, Japan).

Mass spectra were recorded on a Bruker ESQUIRE 3000 PLUS spectrometer (ESI detector, Billerica, MA, USA) or by GC-MS analyses. 
GC-MS analyses involved the use of an HP-6890 gas chromatograph equipped with a 5973 mass detector, using an HP-5MS column $(30 \mathrm{~m} \times 0.25 \mathrm{~mm}, 0.25-\mu \mathrm{m}$ film thickness; Hewlett Packard, Palo Alto, CA, USA) with the following temperature program: $60^{\circ}(1 \mathrm{~min})$, then $6^{\circ} / \mathrm{min}$ to $150^{\circ}$ (held at $1 \mathrm{~min}$ ), then $12^{\circ} / \mathrm{min}$ to $280^{\circ}$ (held $5 \mathrm{~min}$ ); carrier gas: He; constant flow $1 \mathrm{~mL} / \mathrm{min}$; split ratio: 1/30; $t_{\mathrm{R}}$ given in minutes.

The values of $t_{R}$ for each compound are as follows: $t_{R}(4) 5.97, t_{R}(8) 8.78, t_{R}(9) 10.53, t_{R}(10) 8.86$, $t_{\mathrm{R}}(\mathbf{1 1}) 12.32, t_{\mathrm{R}}(\mathbf{1 2}) 12.42, t_{\mathrm{R}}(\mathbf{1 3}) 11.93, t_{\mathrm{R}}(\mathbf{1 5}) 14.58, t_{\mathrm{R}}(\mathbf{1 7}) 8.67, t_{\mathrm{R}}(\mathbf{1 8}) 5.81, t_{\mathrm{R}}(\mathbf{1 9}) 12.63$, and $t_{\mathrm{R}}(\mathbf{2 0}) 7.07$.

3.3. Stereoselective Preparation of (S)- and (R)-(2,6,6-Trimethyltetrahydro-2H-pyran-2-yl)methanol Starting from (R)- and (S)-Linalool, Respectively

\subsection{1. (R)-2,6-Dimethyloct-7-ene-2,6-diol (-)-13}

$(-)$-(R)-Linalool $10(60 \mathrm{~g}, 389 \mathrm{mmol})$, acetic anhydride $(50 \mathrm{~mL}, 529 \mathrm{mmol})$, pyridine $(45 \mathrm{~mL}$, $559 \mathrm{mmol})$, and DMAP ( $1 \mathrm{~g}, 8.2 \mathrm{mmol})$ were heated at reflux under a static atmosphere of nitrogen until complete acetylation of the starting alcohol ( $2 \mathrm{~h}$ by TLC analysis). The reaction mixture was then cooled and quenched by addition to a mixture of water and crushed ice followed by extraction with diethyl ether $(2 \times 250 \mathrm{~mL})$. The combined organic phases were washed in turn with water, and saturated with $\mathrm{NaHCO}_{3}$ solution $(3 \times 200 \mathrm{~mL})$ and brine. The organic phase was dried $\left(\mathrm{Na}_{2} \mathrm{SO}_{4}\right)$ and concentrated in vacuo. The residue was purified by distillation to afford colorless $(R)$-linalool acetate 12 ( $62.9 \mathrm{~g}$, 82\% yield, $94 \%$ purity by GC analysis).

A sample of acetate $12(24 \mathrm{~g}, 122 \mathrm{mmol})$ was dissolved in $\mathrm{CH}_{2} \mathrm{Cl}_{2}(100 \mathrm{~mL})$ and treated with $m$-chloroperbenzoic acid $(31 \mathrm{~g}, 77 \% w / w, 138 \mathrm{mmol})$ stirring at $0{ }^{\circ} \mathrm{C}$ until completion of the reaction (TLC monitoring). The $m$-chlorobenzoic acid formed was removed by filtration and the liquid phase was washed in turn with aqueous $\mathrm{Na}_{2} \mathrm{SO}_{3}(10 \% w / w)$, aqueous $\mathrm{NaHCO}_{3}$ (saturated solution) and brine. The organic phase was dried $\left(\mathrm{Na}_{2} \mathrm{SO}_{4}\right)$, concentrated under reduced pressure and the residue was diluted with dry THF $(60 \mathrm{~mL})$. The aforementioned solution was added dropwise to a stirred suspension of $\mathrm{LiAlH}_{4}(6 \mathrm{~g}, 158 \mathrm{mmol})$ in dry THF $(200 \mathrm{~mL})$. The reaction was stirred at reflux until the starting epoxide was completely transformed into the diol 13 ( $5 \mathrm{~h}$, TLC analysis); then, the mixture was cooled $\left(0^{\circ} \mathrm{C}\right)$, diluted with diethyl ether $(300 \mathrm{~mL})$, and quenched by dropwise addition of $40 \%$ aqueous solution of $\mathrm{NaOH}(50 \mathrm{~mL})$, stirring vigorously for $1 \mathrm{~h}$. The resulting heterogeneous mixture was filtered on a celite pad and the organic phase was washed with brine, before being dried $\left(\mathrm{Na}_{2} \mathrm{SO}_{4}\right)$ and concentrated under reduced pressure. The residue was purified by chromatography using n-hexane/AcOEt (8:2-1:1) as an eluent to afford pure ( $R$ )-2,6-dimethyloct-7-ene-2,6-diol 13 (17.8 g, $85 \%$ yield $)$ as a colorless oil which solidified on standing; $[\alpha]_{\mathrm{D}}^{20}=-9.9\left(c 2, \mathrm{CHCl}_{3}\right)$. A sample of the diol was recrystallized from hexane. The collected crystals showed $98 \%$ purity by GC analysis; melting point (mp): $55-56{ }^{\circ} \mathrm{C} ;[\alpha]_{\mathrm{D}}^{20}=-10.4\left(c 2.1, \mathrm{CHCl}_{3}\right) ;{ }^{1} \mathrm{H} \mathrm{NMR}\left(400 \mathrm{MHz}, \mathrm{CDCl}_{3}\right): \delta 5.92(\mathrm{dd}, J=17.4$, $10.8 \mathrm{~Hz}, 1 \mathrm{H}), 5.21(\mathrm{dd}, J=17.4,1.2 \mathrm{~Hz}, 1 \mathrm{H}), 5.05(\mathrm{dd}, J=10.8,1.2 \mathrm{~Hz}, 1 \mathrm{H}), 1.69(\mathrm{br} \mathrm{s}, 2 \mathrm{H}), 1.59-1.49(\mathrm{~m}$, $2 \mathrm{H}), 1.49-1.34(\mathrm{~m}, 4 \mathrm{H}), 1.29(\mathrm{~s}, 3 \mathrm{H}), 1.21(\mathrm{~s}, 6 \mathrm{H}) .{ }^{13} \mathrm{C} \mathrm{NMR}\left(100 \mathrm{MHz}, \mathrm{CDCl}_{3}\right): \delta 145.1(\mathrm{CH}), 111.6\left(\mathrm{CH}_{2}\right)$, $73.2(\mathrm{C}), 71.0(\mathrm{C}), 44.1\left(\mathrm{CH}_{2}\right), 42.6\left(\mathrm{CH}_{2}\right), 29.2(\mathrm{Me}), 27.7(\mathrm{Me}), 18.6\left(\mathrm{CH}_{2}\right)$.

GC-MS $m / z$ (relative intensity): $154\left(\mathrm{M}^{+}-\mathrm{H}_{2} \mathrm{O},<1\right), 139$ (11), 121 (19), 109 (8), 93 (10), 81 (37), 71 (100), 59 (33), 43 (46).

\subsection{2. (R)-2,6-Dimethylheptane-1,2,6-triol (+)-14}

An oxygen stream containing ozone $\left(0.1\right.$ mole/hour) was bubbled into a cooled $\left(-70{ }^{\circ} \mathrm{C}\right)$ solution of the diol (-)-13 (14 g, $81.3 \mathrm{mmol})$ in $\mathrm{CH}_{2} \mathrm{Cl}_{2} / \mathrm{MeOH}(3: 1 \mathrm{v} / v, 280 \mathrm{~mL})$. As soon as the solution took a persistent light-blue color, the ozone addition was stopped and the oxygen stream was switched to a nitrogen stream. After a few minutes the solution became pale yellow and $\mathrm{NaBH}_{4}(5 \mathrm{~g}, 132.2 \mathrm{mmol})$ was added portionwise. The reaction was slowly allowed to reach $\mathrm{rt}$ and set aside overnight. The excess of hydride was then quenched by addition of acetic acid $(50 \mathrm{~mL})$. After excluding the presence of residual peroxides (negative KI/starch test) the solvents and the excess of acetic acid were removed 
under reduced pressure and the residue was diluted with water $(80 \mathrm{~mL})$ and extracted with $n$-butanol $(4 \times 100 \mathrm{~mL})$. The combined organic phases were washed with brine, before being dried $\left(\mathrm{Na}_{2} \mathrm{SO}_{4}\right)$ and concentrated under reduced pressure. The residue was purified by chromatography eluting first with $n$-hexane/AcOEt (1:1) and then increasing the polarity using AcOEt/MeOH (2:1) to afford pure $(+)-(R)-2,6$-dimethylheptane-1,2,6-triol 14 as a thick, colorless oil (12.9 g, 90\% yield).

$[\alpha]_{\mathrm{D}}^{20}=+2.9\left(\right.$ c 4.7, $\left.\mathrm{CHCl}_{3}\right)$; MS (ESI): $199.1\left(\mathrm{M}^{+}+\mathrm{Na}\right)$

Due to the strong intermolecular hydrogen bonding, ${ }^{1} \mathrm{H}$ and ${ }^{13} \mathrm{C}-\mathrm{NMR}$ analysis of the latter compound were not clear and did not allow an unambiguous characterization of compound 14. Therefore, we prepared the derivative $\mathbf{1 5}$ that was fully characterized. The obtained analytical data substantiated the chemical structure of 15, and thus, the structure of triol $\mathbf{1 4}$. Accordingly, a sample of triol (+)-14 $(200 \mathrm{mg}, 1.13 \mathrm{mmol})$ was dissolved in acetone $(10 \mathrm{~mL})$ and treated with 2,2-dimethoxypropane $(5 \mathrm{~mL})$ and pyridinium $p$-toluenesulfonate $(0.1 \mathrm{~g}, 0.40 \mathrm{mmol})$, and then stirred at $\mathrm{rt}$ for $8 \mathrm{~h}$. Next, $\mathrm{Et}_{3} \mathrm{~N}(2 \mathrm{~mL})$ was added and the solvents were removed under reduced pressure. The residue was partitioned between EtOAc $(50 \mathrm{~mL})$ and water $(50 \mathrm{~mL})$ and the organic phase was washed with water and with brine, before being dried $\left(\mathrm{Na}_{2} \mathrm{SO}_{4}\right)$ and concentrated in vacuo. The obtained pale-yellow oil was purified by chromatography using $n$-hexane/AcOEt (8:2-1:1) as an eluent to afford pure (+)-(R)-2-methyl-5-(2,2,4-trimethyl-1,3-dioxolan-4-yl)pentan-2-ol 15 (215 mg, $88 \%)$.

$[\alpha]_{\mathrm{D}}^{20}=+2.3\left(\right.$ c 3.2, $\left.\mathrm{CHCl}_{3}\right)$

${ }^{1} \mathrm{H}$ NMR $\left(400 \mathrm{MHz}, \mathrm{CDCl}_{3}\right): \delta 3.79(\mathrm{~d}, J=8.3 \mathrm{~Hz}, 1 \mathrm{H}), 3.71(\mathrm{~d}, J=8.3 \mathrm{~Hz}, 1 \mathrm{H}), 1.72-1.33(\mathrm{~m}, 7 \mathrm{H})$, $1.40(\mathrm{~s}, 3 \mathrm{H}), 1.38(\mathrm{~s}, 3 \mathrm{H}), 1.28(\mathrm{~s}, 3 \mathrm{H}), 1.22(\mathrm{~s}, 6 \mathrm{H})$.

${ }^{13} \mathrm{C} \mathrm{NMR}\left(100 \mathrm{MHz}, \mathrm{CDCl}_{3}\right): \delta 109.0(\mathrm{C}), 81.2(\mathrm{C}), 74.0\left(\mathrm{CH}_{2}\right), 70.9(\mathrm{C}), 44.3\left(\mathrm{CH}_{2}\right), 40.5\left(\mathrm{CH}_{2}\right), 29.3(\mathrm{Me})$, $29.2(\mathrm{Me}), 27.2(\mathrm{Me}), 27.1(\mathrm{Me}), 24.8(\mathrm{Me}), 19.3\left(\mathrm{CH}_{2}\right)$.

GC-MS m/z (relative intensity): 201 (M+Me, 31), 183 (16), 141 (9), 123 (100), 115 (92), 107 (10), 97 (19), 81 (39), 72 (52), 59 (50), 43 (75).

MS (ESI): $239.1\left(\mathrm{M}^{+}+\mathrm{Na}\right)$.

\subsection{3. (R)-2-Methyl-5-(2-methyloxiran-2-yl)pentan-2-ol (-)-9}

A stirred solution of triol (+)-14 $(8.2 \mathrm{~g}, 46.5 \mathrm{mmol})$ in dry THF $(60 \mathrm{~mL})$ was treated at $-15{ }^{\circ} \mathrm{C}$ with freshly prepared LDA ( $44 \mathrm{~mL}$ of a $2.4 \mathrm{M}$ solution in THF). After ten minutes, a solution of tosyl chloride $(9.7 \mathrm{~g}, 50.9 \mathrm{mmol})$ in dry THF $(30 \mathrm{~mL})$ was added dropwise. The mixture was stirred at $0{ }^{\circ} \mathrm{C}$ until complete transformation of the starting triol $(3 \mathrm{~h})$. Then, the reaction was quenched by pouring into a mixture of saturated $\mathrm{NH}_{4} \mathrm{Cl}$ solution and crushed ice followed by extraction with diethyl ether $(2 \times 200 \mathrm{~mL})$. The combined organic phases were washed in turn with saturated $\mathrm{NaHCO}_{3}$ solution and brine. The organic solution was dried $\left(\mathrm{Na}_{2} \mathrm{SO}_{4}\right)$ and concentrated in vacuo. The residue was purified by chromatography using $n$-hexane/AcOEt (9:1-1:1) as an eluent to afford pure (-)-(R)-2-methyl-5-(2-methyloxiran-2-yl)pentan-2-ol 9 as a colorless oil (5.9 g, 80\% yield).

$[\alpha]_{\mathrm{D}}^{20}=-6.2\left(c 5.2, \mathrm{CHCl}_{3}\right)$

${ }^{1} \mathrm{H}$ NMR $\left(400 \mathrm{MHz}, \mathrm{CDCl}_{3}\right): \delta 2.62(\mathrm{~d}, J=4.8 \mathrm{~Hz}, 1 \mathrm{H}), 2.58(\mathrm{~d}, J=4.8 \mathrm{~Hz}, 1 \mathrm{H}), 1.67-1.41(\mathrm{~m}, 7 \mathrm{H})$, $1.32(\mathrm{~s}, 3 \mathrm{H}), 1.22(\mathrm{~s}, 6 \mathrm{H})$.

${ }^{13} \mathrm{C} \mathrm{NMR}\left(100 \mathrm{MHz}, \mathrm{CDCl}_{3}\right): \delta 70.7(\mathrm{C}), 56.9(\mathrm{C}), 53.8\left(\mathrm{CH}_{2}\right), 43.6\left(\mathrm{CH}_{2}\right), 36.9\left(\mathrm{CH}_{2}\right), 29.3(\mathrm{Me}), 29.1(\mathrm{Me})$, $20.8(\mathrm{Me}), 19.9\left(\mathrm{CH}_{2}\right)$.

MS (ESI): $181.1\left(\mathrm{M}^{+}+\mathrm{Na}\right)$. 


\subsection{4. (S)-(2,6,6-Trimethyltetrahydro-2H-pyran-2-yl)methanol (+)-8}

A stirred solution of epoxide (-)-9 $(5.6 \mathrm{~g}, 35.4 \mathrm{mmol})$ in $\mathrm{CH}_{2} \mathrm{Cl}_{2}(50 \mathrm{~mL})$ was treated at $0{ }^{\circ} \mathrm{C}$ with (+)-10-camphorsulfonic acid $(100 \mathrm{mg}, 0.43 \mathrm{mmol})$. As soon as the starting epoxide was no longer detectable by TLC analysis $(2 \mathrm{~h})$, the reaction was quenched by addition of a saturated $\mathrm{NaHCO}_{3}$ solution $(40 \mathrm{~mL})$ and was extracted with $\mathrm{CH}_{2} \mathrm{Cl}_{2}(2 \times 60 \mathrm{~mL})$. The combined organic phases were dried $\left(\mathrm{Na}_{2} \mathrm{SO}_{4}\right)$ and concentrated in vacuo. The residue was purified by chromatography using $n$-hexane/ $\mathrm{Et}_{2} \mathrm{Ot}(9: 1-2: 1)$ as an eluent to afford pure (+)-(S)-(2,6,6-trimethyltetrahydro-2H-pyran-2-yl)methanol 8 as a colorless oil ( $4.8 \mathrm{~g}, 86 \%$ yield).

$[\alpha]_{\mathrm{D}}^{20}=+9.8\left(\right.$ c 3.4, $\left.\mathrm{CHCl}_{3}\right)$

${ }^{1} \mathrm{H}$ NMR $\left(400 \mathrm{MHz}, \mathrm{CDCl}_{3}\right): \delta 3.32(\mathrm{~d}, J=10.6 \mathrm{~Hz}, 1 \mathrm{H}), 3.24(\mathrm{~d}, J=10.6 \mathrm{~Hz}, 1 \mathrm{H}), 2.28(\mathrm{br} \mathrm{s}, 1 \mathrm{H})$, $1.84-1.58(\mathrm{~m}, 3 \mathrm{H}), 1.55-1.47(\mathrm{~m}, 1 \mathrm{H}), 1.41-1.25(\mathrm{~m}, 2 \mathrm{H}), 1.25(\mathrm{~s}, 3 \mathrm{H}), 1.19(\mathrm{~s}, 3 \mathrm{H}), 1.17(\mathrm{~s}, 3 \mathrm{H})$.

${ }^{13} \mathrm{C} \mathrm{NMR}\left(100 \mathrm{MHz}, \mathrm{CDCl}_{3}\right): \delta 73.3(\mathrm{C}), 71.8(\mathrm{C}), 70.6\left(\mathrm{CH}_{2}\right), 36.4\left(\mathrm{CH}_{2}\right), 32.2(\mathrm{Me}), 30.3\left(\mathrm{CH}_{2}\right), 28.1(\mathrm{Me})$, $24.3(\mathrm{Me}), 16.1\left(\mathrm{CH}_{2}\right)$.

GC-MS m/z (relative intensity): 143 (M+Me, 2), 127 (59), 109 (100), 97 (3), 81 (4), 75 (4), 69 (49), 59 (12), 43 (45).

3.3.5. Chemical Correlation of (+)-(2,6,6-Trimethyltetrahydro-2H-pyran-2-yl)methanol 8 with (+)-(S)-Cinenic Acid 11

Jones reagent $(5 \mathrm{mmol})$ was added dropwise to a stirred solution of the alcohol (+)-8 $(0.2 \mathrm{~g}$, $1.26 \mathrm{mmol}, 95 \%$ ee) in acetone $(15 \mathrm{~mL})$ at $0{ }^{\circ} \mathrm{C}$. The reaction was allowed to reach $\mathrm{rt}$ and stirring was prolonged since TLC analysis indicated complete transformation of the intermediate aldehyde into the corresponding acid (one hour). The reaction was then quenched by dilution with water $(60 \mathrm{~mL})$ and extraction with diethyl ether $(2 \times 70 \mathrm{~mL})$. The organic phase was washed with water and with brine, before being dried $\left(\mathrm{Na}_{2} \mathrm{SO}_{4}\right)$, and concentrated under reduced pressure. The residue was purified by chromatography using $n$-hexane/ethyl acetate (9:1-7:3) as an eluent to give pure (+)-(S)-2,6,6-trimethyltetrahydro-2H-pyran-2-carboxylic acid $\mathbf{1 1}$ as a colorless oil which crystallized on standing (195 $\mathrm{mg}, 90 \%$ yield, $94 \%$ purity by GC-MS analysis).

$[\alpha]_{\mathrm{D}}^{20}=+2.6\left(c 4, \mathrm{CHCl}_{3}\right)$

${ }^{1} \mathrm{H}$ NMR $\left(400 \mathrm{MHz}, \mathrm{CDCl}_{3}\right): \delta 9.95$ (br s, $\left.1 \mathrm{H}\right), 2.11-2.02(\mathrm{~m}, 1 \mathrm{H}), 1.80-1.62(\mathrm{~m}, 2 \mathrm{H}), 1.56-1.47(\mathrm{~m}, 3 \mathrm{H})$, $1.45(\mathrm{~s}, 3 \mathrm{H}), 1.28(\mathrm{~s}, 3 \mathrm{H}), 1.24(\mathrm{~s}, 3 \mathrm{H})$.

${ }^{13} \mathrm{C}$ NMR $\left(100 \mathrm{MHz}, \mathrm{CDCl}_{3}\right): \delta 178.5(\mathrm{C}), 75.2(\mathrm{C}), 74.4(\mathrm{C}), 35.9\left(\mathrm{CH}_{2}\right), 32.0\left(\mathrm{CH}_{2}\right), 30.1(\mathrm{Me}), 27.7(\mathrm{Me})$, $27.4(\mathrm{Me}), 16.4\left(\mathrm{CH}_{2}\right)$.

GC-MS m/z (relative intensity): 157 (M+-Me, 2), 139 (4), 127 (58), 109 (100), 95 (3), 69 (62), 59 (14), 43 (57).

\subsection{6. (S)-2,6-Dimethyloct-7-ene-2,6-diol (+)-13}

Coriander oil $(60 \mathrm{~g})$, acetic anhydride $(50 \mathrm{~mL}, 529 \mathrm{mmol})$, pyridine $(45 \mathrm{~mL}, 556 \mathrm{mmol})$, and DMAP $(1 \mathrm{~g}, 8,2 \mathrm{mmol})$ were heated at reflux under a static atmosphere of nitrogen until complete acetylation of the (+)-(S)-linalool ( $2 \mathrm{~h}$ by TLC analysis). The reaction mixture was then cooled and quenched by addition to a mixture of water and crushed ice followed by extraction with diethyl ether $(2 \times 200 \mathrm{~mL})$. The combined organic phases were washed in turn with water, before being saturated $\mathrm{NaHCO}_{3}$ solution $(3 \times 200 \mathrm{~mL})$ and brine. The organic phase was dried $\left(\mathrm{Na}_{2} \mathrm{SO}_{4}\right)$ and concentrated in vacuo. The residue was purified by distillation to afford colorless (+)-(S)-linalool acetate $\mathbf{1 2}$ (51.2 g, 91\% purity by GC analysis).

A sample of acetate (+)-12 (28 g, $142.6 \mathrm{mmol})$ was dissolved in $\mathrm{CH}_{2} \mathrm{Cl}_{2}(120 \mathrm{~mL})$ and treated with $m$-chloroperbenzoic acid $(34 \mathrm{~g}, 77 \% \mathrm{w} / \mathrm{w}, 151.7 \mathrm{mmol})$ stirring at $0{ }^{\circ} \mathrm{C}$ until completion 
of the reaction (TLC monitoring). The $m$-chlorobenzoic acid formed was removed by filtration and the liquid phase was washed in turn with aqueous $\mathrm{Na}_{2} \mathrm{SO}_{3}(10 \% w / w)$, aqueous $\mathrm{NaHCO}_{3}$ (saturated solution), and brine. The organic phase was dried $\left(\mathrm{Na}_{2} \mathrm{SO}_{4}\right)$, concentrated under reduced pressure and the residue was diluted with dry THF $(60 \mathrm{~mL})$. The aforementioned solution was added dropwise to a stirred suspension of $\mathrm{LiAlH}_{4}(6.5 \mathrm{~g}, 171.3 \mathrm{mmol})$ in dry THF $(200 \mathrm{~mL})$. The reaction was stirred at reflux until the starting epoxide was completely transformed in the diol (+)-13 (5 h, TLC analysis); then, the mixture was cooled $\left(0{ }^{\circ} \mathrm{C}\right)$, diluted with diethyl ether $(300 \mathrm{~mL})$, and quenched by dropwise addition of $40 \%$ aqueous solution of $\mathrm{NaOH}(50 \mathrm{~mL})$, stirring vigorously for $1 \mathrm{~h}$. The resulting heterogeneous mixture was filtered on a celite pad and the organic phase was washed with brine, before being dried $\left(\mathrm{Na}_{2} \mathrm{SO}_{4}\right)$ and concentrated under reduced pressure. The residue was purified by chromatography using $n$-hexane/AcOEt (8:2-1:1) as an eluent to afford pure (+)-(S)-2,6-dimethyloct-7-ene-2,6-diol 13 (19.1 g, 78\% yield) as a colorless thick oil, showing $[\alpha]_{\mathrm{D}}^{20}=+5.3\left(c 3.5, \mathrm{CHCl}_{3}\right)$. The diol was then recrystallized three times from hexane. The third crystal crop (6.8 g, recrystallization yield $36 \%$ ) showed $98 \%$ purity by GC analysis; mp: $52-53{ }^{\circ} \mathrm{C} ;[\alpha]_{\mathrm{D}}^{20}=+10.1\left(c 3.5, \mathrm{CHCl}_{3}\right)$, corresponding to $96 \%$ ee. ${ }^{1} \mathrm{H}-\mathrm{NMR},{ }^{13} \mathrm{C}-\mathrm{NMR}$, and GC-MS were superimposable to those reported for the $(-)-(R)$ isomer.

\subsection{7. (S)-2,6-Dimethylheptane-1,2,6-triol (-)-14}

According to the procedure outlined for the synthesis of triol (+)-14, diol (+)-13 (96\% ee, $98 \%$ chemical purity) gave, in $91 \%$ yield, $(-)-14$ as a colorless thick oil with $[\alpha]_{\mathrm{D}}^{20}=-2.8\left(c 3.5, \mathrm{CHCl}_{3}\right)$.

\subsection{8. (S)-2-Methyl-5-(2-methyloxiran-2-yl)pentan-2-ol (+)-9}

According to the procedure outlined for the synthesis of epoxide (-)-9, triol (-)-14 (96\% ee) gave, in $76 \%$ yield, (+)-9 as a colorless oil with $[\alpha]_{\mathrm{D}}^{20}=+6.0\left(c 4.1, \mathrm{CHCl}_{3}\right)$ and $95 \%$ chemical purity by GC; ${ }^{1} \mathrm{H}-\mathrm{NMR},{ }^{13} \mathrm{C}-\mathrm{NMR}$, and MS (ESI) were superimposable to those reported for the (-)-(R) isomer.

\subsection{9. (R)-(2,6,6-Trimethyltetrahydro-2H-pyran-2-yl)methanol (-)-8}

According to the procedure outlined for the synthesis of alcohol (+)-8, epoxide (+)-9 (96\% ee, $95 \%$ chemical purity) gave, in $88 \%$ yield, (-)-8 as a colorless oil with $[\alpha]_{\mathrm{D}}^{20}=-10.0\left(c 3.1, \mathrm{CHCl}_{3}\right)$ and $95 \%$ chemical purity by GC.

\subsection{Synthesis of Racemic (2,6,6-Trimethyltetrahydro-2H-pyran-2-yl)methanol}

\subsubsection{2-Ethynyl-2,6,6-trimethyltetrahydro-2H-pyran}

A solution of ethynylmagnesium bromide ( $390 \mathrm{~mL}, 0.9 \mathrm{M}$ in THF) was added dropwise at $-70{ }^{\circ} \mathrm{C}$ to a stirred solution of 6-methylhept-5-en-2-one 16 ( $40 \mathrm{~g}, 317 \mathrm{mmol})$ in dry THF $(100 \mathrm{~mL})$ under a static atmosphere of nitrogen. The reaction was allowed to reach $\mathrm{rt}$, and after $2 \mathrm{~h}$, was poured into a mixture of crushed ice $(300 \mathrm{~g})$ and saturated $\mathrm{NH}_{4} \mathrm{Cl}$ solution $(300 \mathrm{~mL})$ followed by extraction with diethyl ether $(2 \times 300 \mathrm{~mL})$. The combined organic phases were washed with water and with brine, before being dried $\left(\mathrm{Na}_{2} \mathrm{SO}_{4}\right)$ and concentrated in vacuo. The residue was purified by distillation (boiling point (bp) $98^{\circ} \mathrm{C}$ at $20 \mathrm{mmHg}$ ) to afford pure 3,7-dimethyloct-6-en-1-yn-3-ol 17 (43.8 g, 91\% yield, 95\% purity by GC-MS analysis).

A solution of the alkynol $17(20 \mathrm{~g}, 131.4 \mathrm{mmol})$ in $\mathrm{HCOOH} / \mathrm{H}_{2} \mathrm{O}(85: 15,25 \mathrm{~mL})$ under a static atmosphere of nitrogen was heated at reflux until complete transformation of the starting propargylic alcohol (half an hour, TLC analysis). After cooling, the reaction was diluted with cool water $(250 \mathrm{~mL})$ and extracted with diethyl ether $(2 \times 150 \mathrm{~mL})$. The combined organic phases were washed in turn with water, with saturated $\mathrm{NaHCO}_{3}$ solution and with brine, before being dried $\left(\mathrm{Na}_{2} \mathrm{SO}_{4}\right)$ and concentrated in vacuo. The residue was purified by distillation (bp $65{ }^{\circ} \mathrm{C}$ at $20 \mathrm{mmHg}$ ) to afford pure 2-ethynyl-2,6,6-trimethyltetrahydro- $2 \mathrm{H}$-pyran $\mathbf{1 8}$ (15.1 g, 75\% yield, $94 \%$ purity by GC-MS analysis) as a colorless oil. 
${ }^{1} \mathrm{H}$ NMR $\left(400 \mathrm{MHz}, \mathrm{CDCl}_{3}\right): \delta 2.34(\mathrm{~s}, 1 \mathrm{H}), 2.01(\mathrm{qt}, J=13.5,3.4 \mathrm{~Hz}, 1 \mathrm{H}), 1.84(\mathrm{dm}, J=13.0 \mathrm{~Hz}, 1 \mathrm{H})$, $1.61(\mathrm{dt}, J=13.5,3.7 \mathrm{~Hz}, 1 \mathrm{H}), 1.55(\mathrm{dm}, J=13.0 \mathrm{~Hz}, 1 \mathrm{H}), 1.47(\mathrm{~s}, 3 \mathrm{H}), 1.46(\mathrm{~s}, 3 \mathrm{H}), 1.43-1.28(\mathrm{~m}, 2 \mathrm{H})$, $1.18(\mathrm{~s}, 3 \mathrm{H})$.

${ }^{13} \mathrm{C} \mathrm{NMR}\left(100 \mathrm{MHz}, \mathrm{CDCl}_{3}\right): \delta 89.0(\mathrm{C}), 73.5(\mathrm{C}), 71.3(\mathrm{CH}), 67.1(\mathrm{C}), 38.3\left(\mathrm{CH}_{2}\right), 36.4\left(\mathrm{CH}_{2}\right), 33.0(\mathrm{Me})$, $32.6(\mathrm{Me}), 25.2(\mathrm{Me}), 17.5\left(\mathrm{CH}_{2}\right)$.

GC-MS m/z (relative intensity): 137 (M+Me, 100), 119 (11), 109 (76), 95 (32), 79 (69), 66 (81), 56 (62), 43 (83).

\subsubsection{2,6,6-Trimethyltetrahydro-2H-pyran-2-carboxylic Acid or Cinenic Acid 11}

A heterogeneous mixture of the alkyne $18(10 \mathrm{~g}, 65.7 \mathrm{mmol})$, sodium periodate $(60 \mathrm{~g}, 280.5 \mathrm{mmol})$ $\mathrm{CCl}_{4}(50 \mathrm{~mL}), \mathrm{CH}_{3} \mathrm{CN}(50 \mathrm{~mL})$, water $(75 \mathrm{~mL})$, and a catalytic amount of $\mathrm{RuCl}_{3}$ hydrate $(40 \% w / w \mathrm{Ru}$, $80 \mathrm{mg}, 0.32 \mathrm{mmol}$ ) was vigorously stirred at rt. When the starting alkyne was no longer detectable by TLC analysis $(24 \mathrm{~h})$, the reaction was diluted with water $(200 \mathrm{~mL})$, acidified using diluted aqueous $\mathrm{HCl}$ and extracted with $\mathrm{CH}_{2} \mathrm{Cl}_{2}(3 \times 120 \mathrm{~mL})$. The combined organic phases were dried $\left(\mathrm{Na}_{2} \mathrm{SO}_{4}\right)$ and were concentrated in vacuo. The residue was purified by chromatography using $n$-hexane/AcOEt (9:1-1:1) as an eluent to afford pure 2,6,6-trimethyltetrahydro-2H-pyran-2-carboxylic acid $\mathbf{1 1}$ as a colorless oil which crystallized on standing ( $10.2 \mathrm{~g}$, $90 \%$ yield, $94 \%$ purity by GC-MS analysis). A sample of the acid was recrystallized from hexane. The collected crystals showed $98 \%$ purity by GC-MS analysis; mp: 83-84 ${ }^{\circ} \mathrm{C} ;{ }^{1} \mathrm{H}-\mathrm{NMR},{ }^{13} \mathrm{C}-\mathrm{NMR}$, and GC-MS were superimposable to those reported above for the $(+)-(S)$-isomer.

\subsubsection{Racemic (2,6,6-Trimethyltetrahydro-2H-pyran-2-yl)methanol 8}

Ethyl chloroformate $(5.5 \mathrm{~mL}, 57.5 \mathrm{mmol})$ was added dropwise at $-10{ }^{\circ} \mathrm{C}$ to a stirred solution of acid $11(9 \mathrm{~g}, 52.3 \mathrm{mmol})$ and $\mathrm{Et}_{3} \mathrm{~N}(8 \mathrm{~mL}, 57.4 \mathrm{mmol})$ in dry THF $(60 \mathrm{~mL})$. After one hour, the precipitate triethylammonium chloride was filtered and the solid was washed with cold THF $(10 \mathrm{~mL})$. The combined liquid phases were added dropwise to a stirred solution of $\mathrm{NaBH}_{4}(5 \mathrm{~g}$, $132.2 \mathrm{mmol})$ in water $(50 \mathrm{~mL})$ keeping the temperature below $10^{\circ} \mathrm{C}$ by external cooling. After complete addition, the reaction was allowed to reach rt, before being stirred at this temperature for $4 \mathrm{~h}$ and quenched by acidification with diluted $\mathrm{HCl}(3 \%$ in water). The obtained mixture was extracted with diethyl ether $(3 \times 100 \mathrm{~mL})$ and the combined organic phases were washed with saturated $\mathrm{NaHCO}_{3}$ solution and with brine, before being dried $\left(\mathrm{Na}_{2} \mathrm{SO}_{4}\right)$ and concentrated in vacuo. The residue was purified by chromatography using $n$-hexane/AcOEt (9:1-7:3) as an eluent to afford pure (2,6,6-trimethyltetrahydro-2H-pyran-2-yl)methanol 8 (6.7 g, 81\% yield) as a colorless oil; ${ }^{1} \mathrm{H}-\mathrm{NMR}$, ${ }^{13} \mathrm{C}-\mathrm{NMR}$, and GC-MS were superimposable to those reported above for the $(+)-(S)$ isomer.

\subsection{Enzyme-Mediated Resolution of (2,6,6-Trimethyltetrahydro-2H-pyran-2-yl)methanol}

3.5.1. Determination of the Enantioselectivity in the Lipase-Catalyzed Acetylation of Racemic Alcohol 8

A solution of the racemic alcohol $8(0.5 \mathrm{~g}$, $3.16 \mathrm{mmol})$, lipase/esterase, vinyl acetate $(5 \mathrm{~mL})$, and $t$-BuOMe $(20 \mathrm{~mL})$ was stirred at $\mathrm{rt}$, and the formation of the acetylated compound was monitored by TLC analysis. The reaction was stopped at the reported conversion (see Table 1) by filtration of the enzyme and evaporation of the solvent at reduced pressure. The residue was then purified by chromatography using hexane-acetate (9:1-7:3) as an eluent. The obtained acetate and the unreacted alcohol were bulb-to-bulb distilled in order to obtain solvent free samples suitable for the accurate measurement of their optical rotation values. The enantiomeric purity of the samples was determined comparing the measured optical rotation values with those of (S)-(2,6,6-trimethyltetrahydro- $2 \mathrm{H}$-pyran-2-yl)methanol 8 and (S)-(2,6,6-trimethyltetrahydro-2H-pyran-2-yl)methanol acetate $(+)-19$ possessing $95 \%$ ee, $[\alpha]_{\mathrm{D}}^{20}=+9.8$ $\left(c 3.4, \mathrm{CHCl}_{3}\right)$ and $[\alpha]_{\mathrm{D}}^{20}=+7.9\left(c 2.9, \mathrm{CHCl}_{3}\right)$, respectively. 
Data analysis for acetate (+)-19: ${ }^{1} \mathrm{H}$ NMR $\left(400 \mathrm{MHz}, \mathrm{CDCl}_{3}\right): \delta 4.02(\mathrm{~d}, J=10.9 \mathrm{~Hz}, 1 \mathrm{H}), 3.86(\mathrm{~d}$, $J=10.9 \mathrm{~Hz}, 1 \mathrm{H}), 2.08(\mathrm{~s}, 3 \mathrm{H}), 1.76-1.58(\mathrm{~m}, 2 \mathrm{H}), 1.56-1.32(\mathrm{~m}, 4 \mathrm{H}), 1.23(\mathrm{~s}, 3 \mathrm{H}), 1.21(\mathrm{~s}, 3 \mathrm{H}), 1.18(\mathrm{~s}, 3 \mathrm{H})$.

${ }^{13} \mathrm{C} \mathrm{NMR}\left(100 \mathrm{MHz}, \mathrm{CDCl}_{3}\right)$ : $\delta 170.9(\mathrm{C}), 71.8(\mathrm{C}), 71.5(\mathrm{C}), 70.9\left(\mathrm{CH}_{2}\right), 36.3\left(\mathrm{CH}_{2}\right), 31.7\left(\mathrm{CH}_{2}\right), 30.8(\mathrm{Me})$, $29.7(\mathrm{Me}), 25.4(\mathrm{Me}), 20.9(\mathrm{Me}), 16.0\left(\mathrm{CH}_{2}\right)$.

GC-MS m/z (relative intensity): 185 (M+-Me, 2), 127 (71), 109 (100), 97 (3), 81 (3), 69 (36), 56 (6), 43 (54).

3.5.2. Large-Scale Resolution of (2,6,6-Trimethyltetrahydro-2H-pyran-2-yl)methanol 8

A solution of the racemic alcohol 8 (10 g, $63.2 \mathrm{mmol})$, Novozym ${ }^{\circledR} 435$ lipase (3 g), vinyl acetate $(10 \mathrm{~mL})$, and $\mathrm{t}-\mathrm{BuOMe}(50 \mathrm{~mL})$ was stirred at $\mathrm{rt}$, and the formation of the acetylated compound was monitored by TLC analysis. The reaction was stopped at $65 \%$ conversion by filtration of the enzyme and evaporation of the solvent at reduced pressure. The residue was then purified by chromatography using hexane-acetate (9:1-7:3) as an eluent. The unreacted alcohol (-)-8 (3.4 g, 34\% yield) showed the following analytical data: $96 \%$ chemical purity by GC-MS, $[\alpha]_{\mathrm{D}}^{20}=-10.1\left(\right.$ c $\left.3.6, \mathrm{CHCl}_{3}\right)$, corresponding to $98 \%$ ee. The obtained acetate (+)-19 was treated with $\mathrm{NaOH}(6 \mathrm{~g}, 0.15 \mathrm{~mol})$ in $\mathrm{MeOH}(80 \mathrm{~mL})$ at reflux for $1 \mathrm{~h}$. After the work-up procedure, the obtained alcohol was submitted again to the resolution procedure using lipase AK $(4 \mathrm{~g})$ as a catalyst, vinyl acetate $(10 \mathrm{~mL})$, and $t$-BuOMe $(50 \mathrm{~mL})$ allowing the acetylation reaction to reach a conversion of about $60 \%$. The unreacted alcohol (+)-8 (3.5 g, 35\% yield) showed the following analytical data: $97 \%$ chemical purity by GC-MS, $[\alpha]_{\mathrm{D}}^{20}=+10.1\left(\right.$ c 3.0, $\left.\mathrm{CHCl}_{3}\right)$, corresponding to $98 \%$ ee. The remaining acetate ( $3.0 \mathrm{~g}, 24 \%$ yield) could be hydrolyzed to recover further alcohol with low ee that could be used in a new resolution procedure.

\subsection{Synthesis of the Enantiomeric Forms of 2,2,6-Trimethyl-6-vinyltetrahydro-2H-pyran}

\subsection{1. (R)-2,6,6-Trimethyltetrahydro-2H-pyran-2-carbaldehyde (-)-20}

A solution of Py. $\mathrm{SO}_{3}$ complex $(2.7 \mathrm{~g}, 17 \mathrm{mmol})$ in dry DMSO $(10 \mathrm{~mL})$ was added in one portion to a stirred solution of alcohol (-)-8 $\left(1 \mathrm{~g}, 6.32 \mathrm{mmol}, 98 \%\right.$ ee) and $\mathrm{Et}_{3} \mathrm{~N}(10 \mathrm{~mL}, 72 \mathrm{mmol})$ in dry DMSO $(15 \mathrm{~mL})$. After complete transformation of the starting alcohol (by TLC analysis, $2 \mathrm{~h}$ ), the reaction was quenched by addition of water $(100 \mathrm{~mL})$ followed by extraction with diethyl ether $(2 \times 80 \mathrm{~mL})$. The combined organic phases were washed in turn with water, diluted $\mathrm{HCl}$ solution, and brine. The organic solution was dried $\left(\mathrm{Na}_{2} \mathrm{SO}_{4}\right)$ and concentrated in vacuo. The residue was purified by chromatography using $n$-hexane $/ \mathrm{Et}_{2} \mathrm{O}(95: 5-8: 2)$ as an eluent to afford pure $(-)-(R)-2,6,6$-trimethyltetrahydro-2H-pyran-2-carbaldehyde $20(810 \mathrm{mg}, 82 \%$ yield, $92 \%$ purity by GC-MS analysis) as a colorless oil.

$[\alpha]_{\mathrm{D}}^{20}=-44.7\left(\right.$ c 3.9, $\left.\mathrm{CHCl}_{3}\right)$

${ }^{1} \mathrm{H}$ NMR $\left(400 \mathrm{MHz}, \mathrm{CDCl}_{3}\right): \delta 9.59(\mathrm{~d}, J=1.7 \mathrm{~Hz}, 1 \mathrm{H}), 2.15(\mathrm{dm}, J=13.3 \mathrm{~Hz}, 1 \mathrm{H}), 1.61-1.35(\mathrm{~m}, 4 \mathrm{H})$, $1.30-1.17(\mathrm{~m}, 1 \mathrm{H}), 1.27(\mathrm{~s}, 3 \mathrm{H}), 1.12(\mathrm{~s}, 3 \mathrm{H}), 1.11(\mathrm{~s}, 3 \mathrm{H})$.

${ }^{13} \mathrm{C} \mathrm{NMR}\left(100 \mathrm{MHz}, \mathrm{CDCl}_{3}\right): \delta 205.5(\mathrm{C}), 78.4(\mathrm{C}), 73.0(\mathrm{C}), 35.7\left(\mathrm{CH}_{2}\right), 31.9(\mathrm{Me}), 29.2\left(\mathrm{CH}_{2}\right), 25.8(\mathrm{Me})$, $24.5(\mathrm{Me}), 16.6\left(\mathrm{CH}_{2}\right)$.

GC-MS m/z (relative intensity): 141 (M+Me, 2), 127 (60), 109 (100), 95 (3), 81 (4), 69 (75), 59 (8), 43 (54).

\subsection{2. (R)-2,2,6-Trimethyl-6-vinyltetrahydro-2H-pyran (+)-4}

A solution of trimethylaluminium in hexane $(3.2 \mathrm{~mL}$ of a $1 \mathrm{M}$ solution) was added dropwise, under a static atmosphere of nitrogen, to a stirred suspension of activated zinc dust ( $3.2 \mathrm{~g}, 48.9 \mathrm{mmol})$, $\mathrm{CH}_{2} \mathrm{I}_{2}(4.2 \mathrm{~g}, 15.7 \mathrm{mmol})$, and dry THF $(20 \mathrm{~mL})$. The temperature of the mixture was kept below $30^{\circ} \mathrm{C}$ by external cooling until the exothermic reaction settled down. The stirring was prolonged at $\mathrm{rt}$ for a further $10 \mathrm{~min}$; then, aldehyde (-)-20 $(0.8 \mathrm{~g}, 5.12 \mathrm{mmol}, 98 \%$ ee) in dry THF $(3 \mathrm{~mL})$ was added dropwise at $0{ }^{\circ} \mathrm{C}$ and the mixture was stirred for one further hour. The reaction was diluted with 
diethyl ether $(100 \mathrm{~mL})$ and was acidified with diluted $\mathrm{HCl}(3 \%$ in water). The ether was separated and the aqueous phase was extracted with further ether $(60 \mathrm{~mL})$. The combined organic phases were washed with water and with brine, before being dried $\left(\mathrm{Na}_{2} \mathrm{SO}_{4}\right)$ and concentrated in vacuo. The residue was purified by chromatography using n-pentane/ $\mathrm{Et}_{2} \mathrm{O}(99: 1-9: 1)$ as an eluent to afford pure (+)-2,2,6-trimethyl-6-vinyltetrahydro- $2 \mathrm{H}$-pyran $4(0.61 \mathrm{~g}, 77 \%$ yield, $93 \%$ purity by GC-MS analysis) as a colorless oil. The bulb-to-bulb distillation $\left(60-65^{\circ} \mathrm{C}, 20 \mathrm{mmHg}\right)$ of the latter compound afforded very pure (+)-4 (99\% purity by GC-MS analysis).

$[\alpha]_{\mathrm{D}}^{20}=+8.9\left(c 3.3, \mathrm{CHCl}_{3}\right)$

${ }^{1} \mathrm{H}$ NMR $\left(400 \mathrm{MHz}, \mathrm{CDCl}_{3}\right): \delta 5.96(\mathrm{ddd}, J=17.8,11.0,0.8 \mathrm{~Hz}, 1 \mathrm{H}), 4.99(\mathrm{dd}, J=17.8,0.8 \mathrm{~Hz}, 1 \mathrm{H}), 4.94$ $(\mathrm{dd}, J=11.0,1.0 \mathrm{~Hz}, 1 \mathrm{H}), 1.89(\mathrm{dm}, J=13.4 \mathrm{~Hz}, 1 \mathrm{H}), 1.78-1.65(\mathrm{~m}, 1 \mathrm{H}), 1.62-1.51(\mathrm{~m}, 1 \mathrm{H}), 1.50-1.32$ $(\mathrm{m}, 3 \mathrm{H}), 1.20(\mathrm{~s}, 3 \mathrm{H}), 1.19(\mathrm{~s}, 3 \mathrm{H}), 1.18(\mathrm{~s}, 3 \mathrm{H})$.

${ }^{13} \mathrm{C}$ NMR $\left(100 \mathrm{MHz}, \mathrm{CDCl}_{3}\right): \delta 147.2(\mathrm{CH}), 110.2\left(\mathrm{CH}_{2}\right), 73.4(\mathrm{C}), 72.2(\mathrm{C}), 36.6\left(\mathrm{CH}_{2}\right), 33.0\left(\mathrm{CH}_{2}\right)$, $32.3(\mathrm{Me}), 31.5(\mathrm{Me}), 27.5(\mathrm{Me}), 16.8\left(\mathrm{CH}_{2}\right)$.

GC-MS m/z (relative intensity): $154\left(\mathrm{M}^{+},<1\right), 139$ (100), 121 (42), 109 (24), 93 (11), 81 (59), 71 (64), 56 (29), 43 (47).

\subsection{3. (S)-2,6,6-Trimethyltetrahydro-2H-pyran-2-carbaldehyde (+)-20}

According to the procedure outlined for the synthesis of aldehyde (-)-20, alcohol (+)-8 (98\% ee) gave, in $85 \%$ yield, aldehyde (+)-20 as a colorless oil with $[\alpha]_{\mathrm{D}}^{20}=+45.4\left(c 3.1, \mathrm{CHCl}_{3}\right)$ and $95 \%$ chemical purity by GC; ${ }^{1} \mathrm{H}-\mathrm{NMR},{ }^{13} \mathrm{C}-\mathrm{NMR}$, and GC-MS were superimposable to those reported for the $(-)-(R)$-isomer.

\subsection{4. (S)-2,2,6-Trimethyl-6-vinyltetrahydro-2H-pyran (-)-4}

According to the procedure outlined for the synthesis of ether (+)-4, aldehyde (+)-20 (98\% ee) gave, in $70 \%$ yield, ether (-)-4 as a colorless oil with $[\alpha]_{\mathrm{D}}^{20}=-9.0\left(\right.$ c $\left.2.1, \mathrm{CHCl}_{3}\right)$ and $95 \%$ chemical purity by GC; ${ }^{13} \mathrm{C}-\mathrm{NMR}$, and GC-MS were superimposable to those reported for the $(+)-(R)$-isomer.

Author Contributions: S.S. and D.D.S. contributed equally to the design, and performed the experiments and analyzed the data; S.S. conceived the study and wrote the paper.

Funding: This research was funded by [Regione Lombardia: POR-FESR 2014-2020] grant number [228775 VIPCAT (Value Added Innovative Protocols for Catalytic Transformations)]

Acknowledgments: The authors thank Regione Lombardia for supporting this study within the project POR-FESR 2014-2020 No. 228775 VIPCAT (Value Added Innovative Protocols for Catalytic Transformations).

Conflicts of Interest: The authors declare no conflict of interest.

\section{References}

1. Winterhalter, P.; Katzenberger, D.; Schreier, P. 6,7-Epoxy-linalool and related oxygenated terpenoids from Carica papaya fruit. Phytochemistry 1986, 25, 1347-1350. [CrossRef]

2. Avonto, C.; Wang, M.; Chittiboyina, A.G.; Avula, B.; Zhao, J.; Khan, I.A. Hydroxylated bisabolol oxides: Evidence for secondary oxidative metabolism in Matricaria chamomilla. J. Nat. Prod. 2013, 76, 1848-1853. [CrossRef] [PubMed]

3. Boivin, T.L.B. Synthetic routes to tetrahydrofuran, tetrahydropyran, and spiroketal units of polyether antibiotics and a survey of spiroketals of other natural products. Tetrahedron 1987, 43, 3309-3362. [CrossRef]

4. Nicolaou, K.C.; Prasad, C.V.C.; Somers, P.K.; Hwang, C.K. Activation of 6-endo over 5-exo hydroxy epoxide openings. Stereoselective and ring selective synthesis of tetrahydrofuran and tetrahydropyran systems. J. Am. Chem. Soc. 1989, 111, 5330-5334. [CrossRef]

5. Nasir, N.M.; Ermanis, K.; Clarke, P.A. Strategies for the construction of tetrahydropyran rings in the synthesis of natural products. Org. Biomol. Chem. 2014, 12, 3323-3335. [CrossRef] [PubMed] 
6. Surburg, H.; Panten, J. Common Fragrance and Flavor Materials: Preparation, Properties and Uses, 6th ed.; Wiley-VCH Verlag GmbH \& Co., KGaA: Weinheim, Germany, 2016; ISBN 9783527331604.

7. Ohta, Y.; Nishimura, K.; Hirose, Y. Studies on the monoterpene fraction of 'geranium oil' from Pelargonium roseum Bourbon. Agric. Biol. Chem. 1964, 28, 5-9. [CrossRef]

8. Strickler, H.; Kováts, E.S. 245. Zur kenntnis ätherischer öle. Zwei monoterpenoxide aus dem sog. «destillierten» limetten-öl (Citrus medica L., var. acida Brandis; Citrus aurantifolia Swingle). Helv. Chim. Acta 1966, 49, 2055-2067. [CrossRef]

9. Williams, P.J.; Strauss, C.R.; Wilson, B. Hydroxylated linalool derivatives as precursors of volatile monoterpenes of muscat grapes. J. Agric. Food Chem. 1980, 28, 766-771. [CrossRef]

10. Engel, K.H.; Tressl, R. Formation of aroma components from nonvolatile precursors in passion fruit. J. Agric. Food Chem. 1983, 31, 998-1002. [CrossRef]

11. Idstein, H.; Herres, W.; Schreier, P. High-resolution gas chromatography-mass spectrometry and -fourier transform infrared analysis of cherimoya (Annona cherimolia, Mill.) volatiles. J. Agric. Food Chem. 1984, 32, 383-389. [CrossRef]

12. Froehlich, O.; Duque, C.; Schreier, P. Volatile constituents of curuba (Passiflora mollissima) fruit. J. Agric. Food Chem. 1989, 37, 421-425. [CrossRef]

13. Boelens, M.H.; Jimenez, R. Chemical composition of the essential oils from the gum and from various parts of Pistacia lentiscus L. (mastic gum tree). Flavour Frag. J. 1991, 6, 271-275. [CrossRef]

14. Nitz, S.; Kollmannsberger, H. Changes in flavour composition during thermal concentration of apricot purée. Z. Lebensm. Unters. Forch. 1993, 197, 541-545. [CrossRef]

15. Chen, S.-H.; Huang, T.-C.; Ho, C.-T.; Tsai, P.-J. Extraction, analysis, and study on the volatiles in roselle tea. J. Agric. Food Chem. 1998, 46, 1101-1105. [CrossRef]

16. Dugo, P.; Cotroneo, A.; Bonaccorsi, I.; Mondello, L. On the genuineness of citrus essential oils. Part LVII. The composition of distilled lime oil. Flavour Frag. J. 1998, 13, 93-97. [CrossRef]

17. Demyttenaere, J.C.R.; Dagher, C.; Sandra, P.; Kallithraka, S.; Verhé, R.; De Kimpe, N. Flavour analysis of greek white wine by solid-phase microextraction-capillary gas chromatography-mass spectrometry. J. Chromatogr. A 2003, 985, 233-246. [CrossRef]

18. Quijano, C.E.; Pino, J.A. Analysis of volatile compounds of cacao maraco (Theobroma bicolor Humb. et Bonpl.) fruit. J. Essent. Oil Res. 2009, 21, 211-215. [CrossRef]

19. Hu, C.-D.; Liang, Y.-Z.; Guo, F.-Q.; Li, X.-R.; Wang, W.-P. Determination of essential oil composition from Osmanthus fragrans tea by GC-MS combined with a chemometric resolution method. Molecules 2010, 15, 3683-3693. [CrossRef] [PubMed]

20. Zeng, L.-B.; Zhang, Z.-R.; Luo, Z.-H.; Zhu, J.-X. Antioxidant activity and chemical constituents of essential oil and extracts of Rhizoma homalomenae. Food Chem. 2011, 125, 456-463. [CrossRef]

21. Hamasaki, T.; Sato, Y.; Hatsuda, Y. Isolation of new metabolites from Aspergillus sydowi and structure of sydowic acid. Agric. Biol. Chem. 1975, 39, 2337-2340. [CrossRef]

22. Zdero, C.; Bohlmann, F. Pseudoguaianolides and other constituents from Anisopappus pinnatifidus and Antiphiona species. Phytochemistry 1989, 28, 1155-1161. [CrossRef]

23. Nagai, M.; Tanaka, O.; Shibata, S. Chemical studies on the oriental plant drugs. XXVI. Saponins and sapogenins of ginseng. The absolute configurations of cinenic acid and panaxadiol. Chem. Pharm. Bull. 1971, 19, 2349-2353. [CrossRef]

24. Brenna, E.; Fuganti, C.; Gatti, F.G.; Serra, S. Biocatalytic methods for the synthesis of enantioenriched odor active compounds. Chem. Rev. 2011, 111, 4036-4072. [CrossRef] [PubMed]

25. Serra, S.; Nobile, I. Chemoenzymatic preparation of the $p$-menth-1,5-dien-9-ol stereoisomers and their use in the enantiospecific synthesis of natural $p$-menthane monoterpenes. Tetrahedron Asymmetry 2011, 22, 1455-1463. [CrossRef]

26. Serra, S.; Cominetti, A.A. An expedient synthesis of linden ether. Nat. Prod. Commun. 2014, 9, $293-296$. [PubMed]

27. Serra, S. Recent advances in the synthesis of carotenoid-derived flavours and fragrances. Molecules 2015, 20, 12817-12840. [CrossRef] [PubMed]

28. Serra, S.; De Simeis, D. A study on the lipase-catalysed acylation of 6,7-dihydroxy-linalool. Nat. Prod. Commun. 2016, 11, 1217-1220. 
29. Serra, S.; De Simeis, D.; Brenna, E. Lipase mediated resolution of cis- and trans-linalool oxide (pyranoid). J. Mol. Catal. B Enzym. 2016, 133, S420-S425. [CrossRef]

30. Vidari, G.; Giori, A.; Dapiaggi, A.; Lanfranchi, G. Asymmetric dihydroxylation of linalool, nerolidol and citronellyl acetate. Enantioselective synthesis of (3S,6S)-tetrahydro-2,2,6-trimethyl-6-vinyl-2H-pyran-3-ol. Tetrahedron Lett. 1993, 34, 6925-6928. [CrossRef]

31. Vidari, G.; Lanfranchi, G.; Pazzi, N.; Serra, S. Studies on the total synthesis of the saponaceolides. 1. Enantioselective synthesis of the spiroketal subunit. Tetrahedron Lett. 1999, 40, 3063-3066. [CrossRef]

32. Aprotosoaie, A.C.; Hăncianu, M.; Costache, I.-I.; Miron, A. Linalool: A review on a key odorant molecule with valuable biological properties. Flavour Frag. J. 2014, 29, 193-219. [CrossRef]

33. Rupe, H.; Lang, G. 2,6-dimethyl-hexan-äthinoxyd. Helv. Chim. Acta 1929, 12, 1133-1141. [CrossRef]

34. Serra, S. Bisabolane sesquiterpenes: Synthesis of $(R)-(+)$-sydowic acid and $(R)-(+)$-curcumene ether. Synlett 2000, 2000, 890-892.

35. Strickler, H.; Ohloff, G. 253. Die chiralität der $\alpha$-cinensäure. Helv. Chim. Acta 1966, 49, 2157-2161. [CrossRef]

36. Carlsen, P.H.J.; Katsuki, T.; Martin, V.S.; Sharpless, K.B. A greatly improved procedure for ruthenium tetroxide catalyzed oxidations of organic compounds. J. Org. Chem. 1981, 46, 3936-3938. [CrossRef]

37. Ishizumi, K.; Koga, K.; Yamada, S. Chemistry of sodium borohydride and diborane. IV. Reduction of carboxylic acids to alcohols with sodium borohydride through mixed carbonic-carboxylic acid anhydrides. Chem. Pharm. Bull. 1968, 16, 492-497. [CrossRef]

38. Serra, S.; Fuganti, C. Enzyme-mediated preparation of enantiomerically pure $p$-menthan-3,9-diols and their use for the synthesis of natural $p$-menthane lactones and ethers. Helv. Chim. Acta 2002, 85, 2489-2502. [CrossRef]

39. Serra, S.; Fuganti, C.; Gatti, F.G. A chemoenzymatic, preparative synthesis of the isomeric forms of $p$-menth-1-en-9-ol: Application to the synthesis of the isomeric forms of the cooling agent 1-hydroxy-2,9-cineole. Eur. J. Org. Chem. 2008, 2008, 1031-1037. [CrossRef]

40. Serra, S. Lipase-mediated resolution of substituted 2-aryl-propanols: Application to the enantioselective synthesis of phenolic sesquiterpenes. Tetrahedron Asymmetry 2011, 22, 619-628. [CrossRef]

41. Serra, S.; Piccioni, O. A new chemo-enzymatic approach to the stereoselective synthesis of the flavors tetrahydroactinidiolide and dihydroactinidiolide. Tetrahedron Asymmetry 2015, 26, 584-592. [CrossRef]

42. Chen, C.S.; Fujimoto, Y.; Girdaukas, G.; Sih, C.J. Quantitative analyses of biochemical kinetic resolutions of enantiomers. J. Am. Chem. Soc. 1982, 104, 7294-7299. [CrossRef]

43. Burdock, G.A. Fenaroli's Handbook of Flavor Ingredients, 6th ed.; CRC Press: Boca Raton, FL, USA, 2010; pp. 1957-1958. ISBN 978-1-4200-9077-2.

44. Tschumi, R.; Bonrath, W.; Tschumi, J. Process of Production of Cyclo-Dehydrolinalool. WO Patent 2016/128423 A1, 18 August 2016.

45. Klein, E.; Farnow, H.; Rojahn, W. Die chemie der linalool-oxide. Liebigs Ann. Chem. 1964, 675, 73-82. [CrossRef]

46. Parikh, J.R.; Doering, W.v.E. Sulfur trioxide in the oxidation of alcohols by dimethyl sulfoxide. J. Am. Chem. Soc. 1967, 89, 5505-5507. [CrossRef]

47. Takai, K.; Hotta, Y.; Oshima, K.; Nozaki, H. Effective methods of carbonyl methylenation using $\mathrm{CH}_{2} \mathrm{I}_{2}-\mathrm{Zn}-\mathrm{Me}_{3} \mathrm{Al}$ and $\mathrm{CH}_{2} \mathrm{Br}_{2}-\mathrm{Zn}-\mathrm{TiCl}_{4}$ system. Tetrahedron Lett. 1978, 19, 2417-2420. [CrossRef]

(C) 2018 by the authors. Licensee MDPI, Basel, Switzerland. This article is an open access article distributed under the terms and conditions of the Creative Commons Attribution (CC BY) license (http://creativecommons.org/licenses/by/4.0/). 